\title{
Blast-induced ground vibration management in deep open pit mines using GIS: A case study
}

\author{
P Balamadeswaran \\ Anna University \\ Chennai, India \\ balamadeswaran@gmail.com
}

\author{
AK Mishra and Phalguni Sen \\ Indian Institute of Technology (ISM) \\ Dhanbad, India
}

\author{
Sreekumar and ON Tiwari \\ Hindustan Copper Limited \\ Balaghat, India
}

\begin{abstract}
Blasting is considered to be one of the significant unit operations in the open pit mines for achieving higher production and productivity. As the blasting operation has been carried out frequently in deep open pit mines, the disturbance in the form of structural damages or psychological issues are also gradually exaggerated with increasing depth and change in the rock characteristics. Safety in terms of environmental effects is one of the significant aspects of a good blasting which can be accomplished possibly through advanced blasting practices and innovative approaches. Generally, the ground vibrations arising from the blasting operation is one of the fundamental reasons for creating unpleasant environmental issues for the mines situated near the population area or any sensitive structures. Similarly, the control of vibration is much helpful to deep open pit operators to achieve their operational objectives closer to the final limits such as wall control and sensitive infrastructure like crusher plant, shaft, buildings, pump house, pipelines and haul roads. Hence, prediction of the ground vibration components is very crucial for designing the safe blast. The intensity of the blastinduced ground vibration is affected by the parameters such as the physical and mechanical properties of the rock mass, characteristics of explosives and the blast design. Based on the plethora of research activity on the subject, different criteria have been designed to specify limits of blast-induced ground vibrations. In spite of the significant research, the criteria vary from one place to another and are not foolproof. This is primarily because of varied rock and blasting conditions. The rock characteristics can vary greatly from one part of a bench to another part, and also can have the directional variability according to discontinuities in the geological formation and structure. In this study, field measurements were carried out at the different benches of a deep open pit copper mine where dissimilar structural lithological characteristics exists and their results were analysed to evaluate blast-induced vibrations according to the type of rock formation. Finally, a thematic mapping indicating the blast-induced vibration level (ppv) for the different rock formations incorporating the structural geological features are prepared using Geographical Information System (GIS) technique. This thematic mapping can be used as effective tool in providing an interesting insight into the influence of rock characteristics on blast-induced vibration level while designing a blast in order to protect the pit slopes and surrounding structures in future.
\end{abstract}

Keywords-Open pit mine; Blasting, Geology; Ground vibrations; Rock mass properties; Rock formation; Geographical Information System.

\section{INTRODUCTION}

The mining and construction industry spends heavy coins on blasting technology, explosives and their safe detonation. It is well known that about $90 \%$ of mineral production comes from surface mines in India. The drilling and blasting operations are considered to be first phase of any production operation in surface mining. Even though the blasting operation is considered to be the important unit operations, many researches indicate that fragmentation accounts for only $20-30 \%$ of the total amount of explosive energy used during the blasting process [1]. Therefore, the remainder of the energy is wasted away in the form of ground vibrations, air-overpressure and flyrock.

Here, the blast induced ground vibrations may cause a significant damage to nearby buildings or various structures and it is well known that these vibrations are dependent on many more factors like type of rock and its properties, geological parameters, maximum charge per delay, distance of the structure from the blasting site, blast geometry, total charge, etc [2]. Hence, it is mandatory for the mine operators to monitor and assess the level of vibrations and make appropriate changes in the field with regard to blast geometry thereby reducing the vibration level significantly for ensuring the eco-friendly mining system.

A Geographical Information System (GIS) is any system that integrates, captures, stores, analyzes shares, manages, and displays data that is linked to location or so called geographic data. GIS streamlines the work flow, reduces staff resources and more importantly responds quickly to ever changing design requirement on site reflecting the complex ground conditions through numerous sensitive receivers.

In any open pit mine blasting, the transfer of seismic energy produced from a blast to a nearby structure is 
generally accomplished predominantly by primary waves [3]. As these seismic waves move through the surrounding rock from an open pit, they are attenuated according to the nature of rock in which they are travelling. The rate of seismic wave attenuation is lower in hard and massive rock formation than in highly jointed rock and softer formations [4]. In a jointed rock formation, the waves will be attenuated to a greater degree as a result of frictional losses at joint surfaces, and less vibration will reach the monitoring station.

The intensity of the blast-induced ground vibration is influenced by parameters such as the physico-mechanical properties of the rock mass, characteristics of the explosive, and the blast design $[5,6]$. The surrounding rock types have also moderate influence on ground vibration as compared to blast design[7]. Besides, the geological discontinuity plays a important role in the transmission of ground vibration $[8,9]$.

In this study, experimental blasts were carried out in different formations of a hard rock, base metal open pit mine located in India to assess the level of ground vibration induced during blasting operations and accordingly a thematic mapping using GIS has been prepared by incorporating the structural geology which will help in identifying the zone of influence of vibrations..

\section{CASe Study}

In our study, 26 shots were carried out in different formations and their vibration velocities were monitored and measured to evaluate the blast-induced ground vibrations in an open pit base metal mine situated in India "Fig. 1 (a)". The vibration monitors were positioned in the field in different patterns by either as single-line array or trilateral array in all the type of rock formations.

\section{A. Location and Geology of the Mine}

The geology of the area consists of a Precambrian basement complex, comprising mainly granitites and basic dyke rocks, and weakly metamorphosed sedimentary rocks of the Chilpi Ghat Series. The composition of the basement complex ranges from granite, adamellite, granodiorite and tonalite. The texture is coarse to medium grained with a gneissic foliation developed in places. The deposit is considered to have formed by repeated hydrothermal activities, accompanied by acidic igneous activities. Granitic ore are formed in the first stage of mineralisation. Hydrothermal solutions were injected through the mylonitised shear zones and spread into fractures, accompanied with potassic alteration. The quartz reef was formed in the second stage of mineral deposition. The sulphide minerals precipitated slightly later than quartz.

However, a huge mineralized quartz reef, (2600 m long by approximately $60 \mathrm{~m}$ wide and over $600 \mathrm{~m}$ down dip) dipping at $60^{\circ}$ to $70^{\circ}$ to the east, occurs in the granitoids. This reef occupies an arc zone representing earlier tectonic activity. The quartz reef is fractured and displaced by late transverse faulting and the adjoining host rock comprising of granite which is altered with predominant pink feldspar.

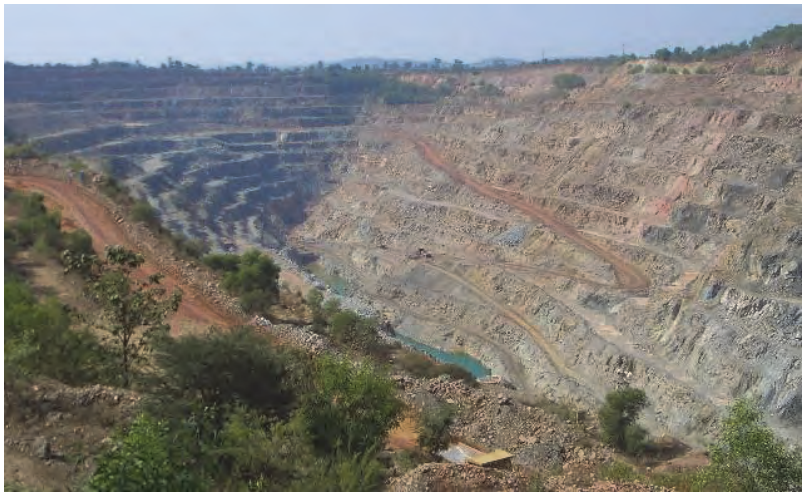

Fig. 1(a). Panoramic View of Mine

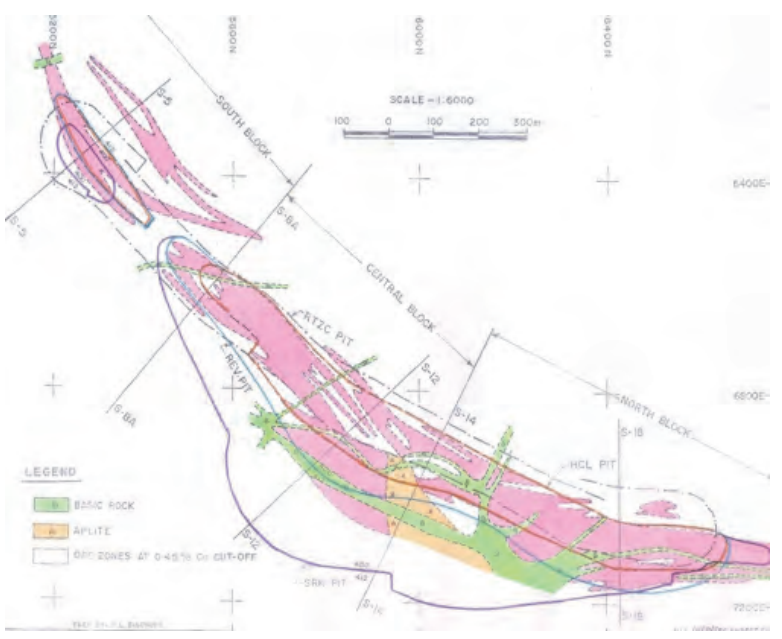

Fig.1. (b). Geological Plan of Blast Site

However, the mineralization is confined to the reef and the altered granite.

\section{Description of the deposit}

From the geological plan of the mine, it was understood clearly that the mineralized zone near the surface has been oxidized and secondary enrichment zone occurs horizontally in an irregular from at the lower part of the oxidized zone "Fig. 1 (b)".

The thin irregular form mineralized quartz veins are observed in the granitoids adjacent to the large mineralized quartz reef. Following the mineralization, the major aplite mass was intruded into the central region of the deposit and a series of basic metadolerite dykes were intruded both in cross cutting attitudes and sub- parallel to the mineralized reef. In general, the metadolerite is not mineralized.

\section{B. Description of the Rock formation}

The rocks of study area are of Proterozoic age and the formation type can be broadly grouped into two divisions, each with distinct characters, separated by an unconformity. The older group consists of basement Granitoids and the younger less metamorphosed sedimentary rocks of Chilpi Ghat series. The cellar rocks have an overlying Precambrian metasediments of Chilpi Ghat Series with an erosional unconformity. The granitic rocks extend in creation from a 
biotite granite to quartz diorite and they are very kaolinised, seriticised and saussuritised in the mineralised zone. The quartz reefs, connected with the rocks have a restricted copper mineralization [10].

The intensity and size of quartz veins varies from place to place. Here, the granitoids are sheared and jointed as shown in "Fig. 2", and the amount of shearing is more evident on the Hanging Wall side of the deposit.

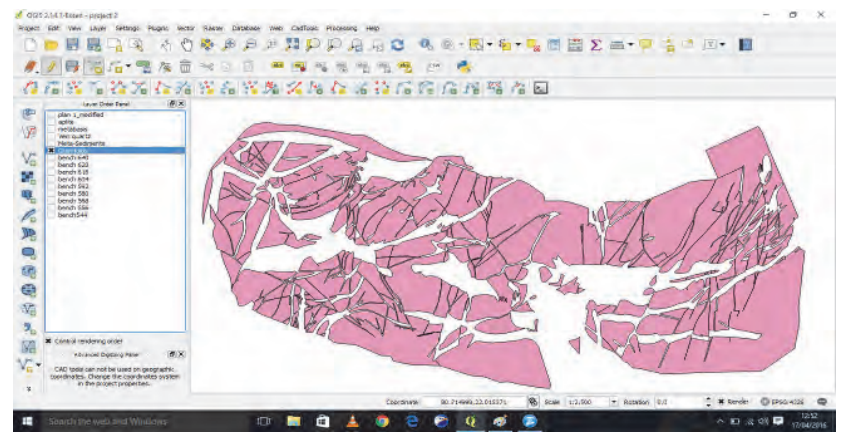

Fig. 2. Distribution of Granitoids

The quartz reef is the principle host of mineralisation and it is sheared and fractured and even bracciated as shown in Fig.3. However, it is massive and compact at places. The veins and veinlets of quartz traverse quietly in granitoids on hanging wall and foot wall of the reef. The reef is also traversed by Aplite and Basic rocks.

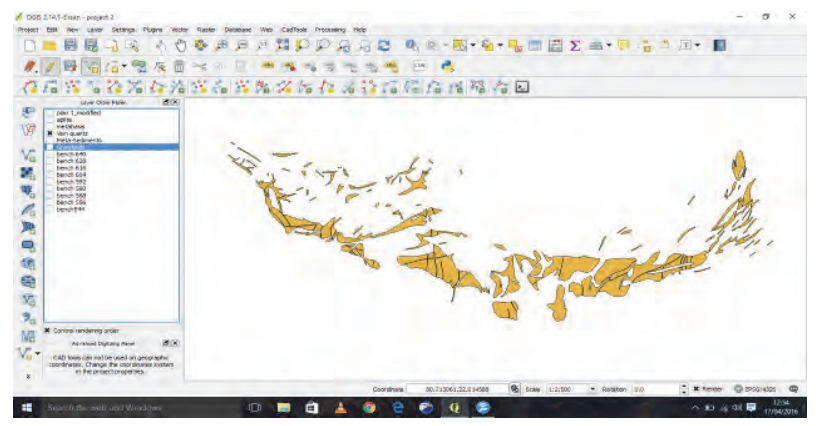

Fig. 3. Distribution of Vein Quartz

Similarly, the basic rocks are the most predominant intrusive rocks in the area. They are the youngest members of the basement complex and also cut across the granitoids, quartz reef and aplites. The contacts are sharp in general and are sheared at places. They vary in width from $1 \mathrm{~m}$ to $60 \mathrm{~m}$. The basic rocks occur in two distinct trends N-S and NW-SE directions. Some of the dykes have displaced the quartz reef and appear to have been emplaced along the fault planes as shown in "Fig. 4". The basic rocks are dark green in colour and fine grained, jointed and highly fractured.

Aplite is the fine grained, equigranular and allotriomorphic granitic rocks with xenomorphic texture. They are pale to light pink in colour which occur only in the central part of deposit like a stock as shown in "Fig. 5" and its width increases in depth only from the depth of $260 \mathrm{~m}$. They cut across the quartz reef and granitoids, and are highly fractured.

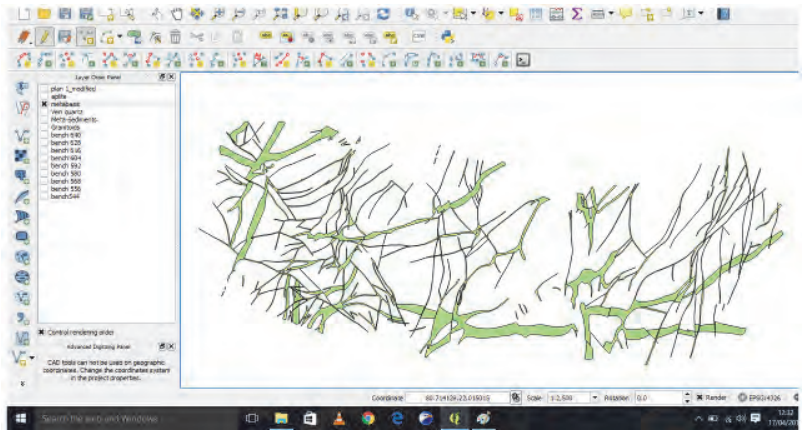

Fig. 4. Distribution of Meta-basis

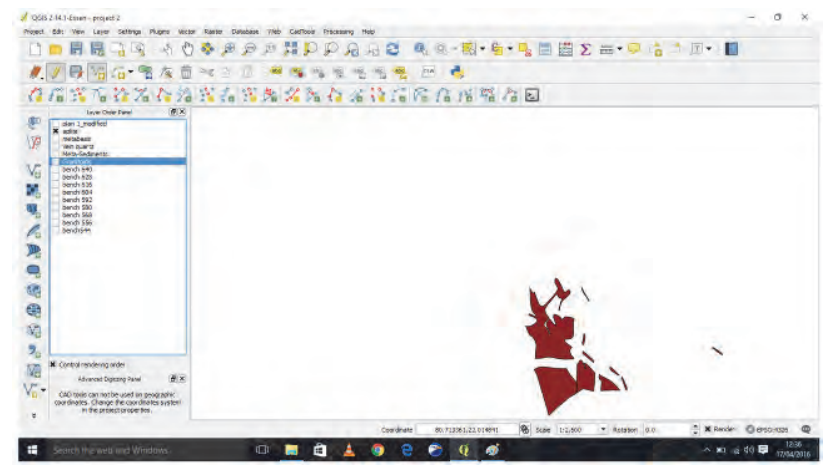

Fig. 5. Distribution of Aplite

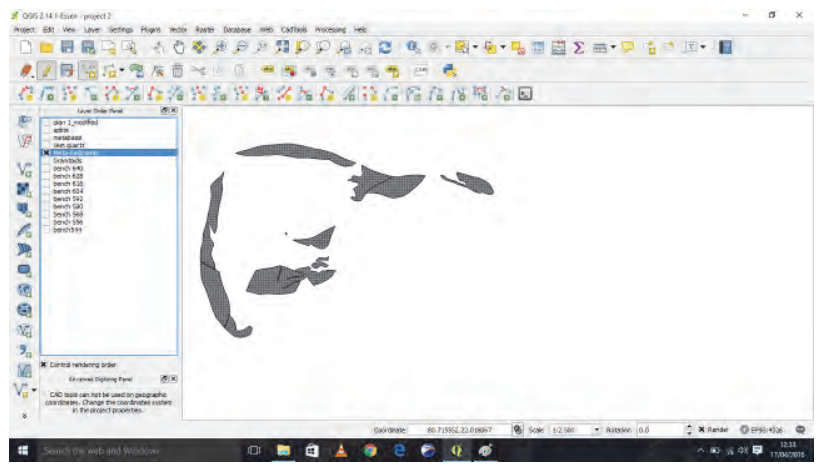

Fig. 6. Distribution of Meta-Sediments

Chilpi ghat series are the younger sedimentary formations lying unconformable over the granitoids in the post mineralisation age as in "Fig. 6". This group consists of Conglomerate, Arkosic grits, Arkose, Sandstone and Phyllites. The matrix is composed of argillaceous, siliceous and ferruginous, materials. The size of the pebble varies from few $\mathrm{cm}$ to $50 \mathrm{~cm}$. Phyllites are light grey to buff coloured show crude foliation.

\section{Mining Method}

The mine of the study area is highly mechanized open pit type producing 2 Million Tonnes of base metal concentrates along with $9 \mathrm{Mm}^{3}$ of overburden annually. The conventional mining method comprising of drilling and blasting which is responsible for producing adequate and convenient materials for the shovel and dumper combination system to carry out the excavation successfully. The drill holes of $165 \mathrm{~mm}$ diameter charged with site mixing slurry explosives and cartridges explosives (which are very negligible in quantity) 
are blasted with delay detonators using the non-electric initiation system mine. The hydraulic excavators of $5.2 \mathrm{~m}^{3}$ and electric rope shovels of $10 \mathrm{~m}^{3}$ are loading the blasted material into the trucks of $85 \mathrm{t}$ and $110 \mathrm{t}$ capacity.

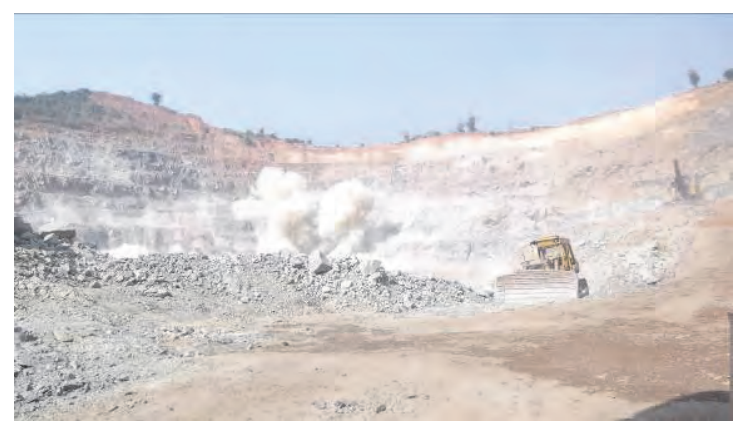

Fig. 7. Blasting from Granitoid Benches

\section{Blast Details}

The blasts were carried out in different type of formations "Fig .7" .Using GIS a thematic map is prepared in which all the blast location and the structural features of the blast zone and its surrounding were mentioned in the scale 1:2500. The Three Core Zones indicates the PPV influence of different Blast zones "Table- $I$ ". According to the blast conducted during our visit we split the mine area into Three Zones,

- $\quad$ North Footwall Zone

- North Hangwall Zone

- South Footwall Zone

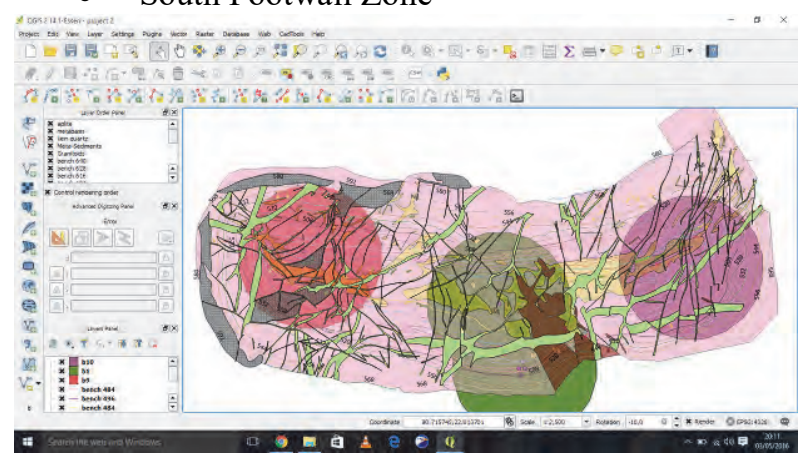

Fig.8. Thematic map showing different zones of blast

\section{ANALYSIS USING GIS}

The GIS model incorporating all the relevant spatial layers showing the different types of rock formation was prepared in order to provide an accurate terrain picture. Then, the geological plan of the levels in which the blasts were carried out has been merged in the GIS tool to provide rock contours of the site [11]. The thematic maps are prepared for the blasts carried out in Granitiods rockmass, Metabasis and in Metasediments using GIS tool indicating the influence of peak particle velocity $(\mathrm{m} / \mathrm{s})$ for the different charge per delay maintaining the other parameters intact. Predicted peak particle velocity (PPV) contours are calculated to clearly illustrate the impact that the proposed blasting had on nearby sensitive receivers based on the
Table I. Blast Details in Open Pit Mine

\begin{tabular}{|c|c|c|c|c|c|c|c|}
\hline $\begin{array}{l}N \\
o\end{array}$ & $\begin{array}{l}\text { Rock } \\
\text { Type }\end{array}$ & $\begin{array}{c}\text { Bench } \\
\text { locatio } \\
n\end{array}$ & $\begin{array}{c}\text { Blasthol } \\
\text { e Depth } \\
\text { Ranges } \\
\text { of hole } \\
\text { (m) }\end{array}$ & $\begin{array}{c}\text { Bu } \\
\text { rde } \\
n \\
(m)\end{array}$ & $\begin{array}{c}\text { Spaci } \\
\text { ng } \\
(m)\end{array}$ & $\begin{array}{c}\text { Char } \\
\text { ge per } \\
\text { Delay } \\
(\mathrm{kg})\end{array}$ & $\begin{array}{c}P P V @ \\
300 \mathrm{~m} \\
(\mathrm{~mm} / \mathrm{sec})\end{array}$ \\
\hline \multirow{3}{*}{1.} & \multirow{3}{*}{$\begin{array}{l}\text { Grani } \\
\text { tiods }\end{array}$} & \multirow{3}{*}{$\begin{array}{c}484 \\
\text { NHW } \\
\& \text { SFW }\end{array}$} & \multirow{3}{*}{$5-14$} & \multirow{3}{*}{3.5} & \multirow{3}{*}{4.0} & 150 & 12.4 \\
\hline & & & & & & 300 & 12.4 \\
\hline & & & & & & 600 & 15.1 \\
\hline \multirow{3}{*}{2.} & \multirow{3}{*}{$\begin{array}{l}\text { Meta } \\
\text { basis }\end{array}$} & \multirow{3}{*}{$\begin{array}{c}448 \\
\text { NHW }\end{array}$} & \multirow{3}{*}{$4-9$} & \multirow{3}{*}{3.5} & \multirow{3}{*}{3.5} & 150 & 6.18 \\
\hline & & & & & & 300 & 10.56 \\
\hline & & & & & & 540 & 11.60 \\
\hline \multirow{3}{*}{3.} & \multirow{3}{*}{$\begin{array}{c}\text { Metas } \\
\text { edime } \\
\text { nts }\end{array}$} & \multirow{3}{*}{$\begin{array}{c}448 \\
\text { SFW }\end{array}$} & \multirow{3}{*}{$12-14$} & \multirow{3}{*}{3.5} & \multirow{3}{*}{3.5} & 200 & 12.2 \\
\hline & & & & & & 300 & 13.66 \\
\hline & & & & & & 1650 & 3.13 \\
\hline
\end{tabular}

ground attenuation constants calculated from the total number of 26 blasts carried out in different formations. The PPV contour plots (thematic maps) were produced using GIS tool as shown in "Fig. 9, $10 \& 11$ " for the various areas where the blasting is proposed in future. These plots are produced to indicate the PPV that was received at the ground surface when the blast charge weight is calculated and maintained to a designed maximum charge quantity $(\mathrm{kg})$ per delay. The interpretation on the analysis of results of ppv obtained for the different rock types "Table-I" are given as below.

\subsubsection{South Footwall Zone}

- In the case of South Footwall Zone, the highest PPV value of $15.10 \mathrm{~mm} / \mathrm{s}$ was produced in granitoids subject to maximum charge of $600 \mathrm{~kg}$ per delay at a distance of $300 \mathrm{~m}$. It was observed that the presence of discontinuity is almost negligible as it is clearly visible from bench slope and geological mapping.

- In the case of metasediments formation, the ppv value of 13.66 was obtained at a distance of $300 \mathrm{~m}$ and it was observed that the presence of discontinuity exists in moderate level.

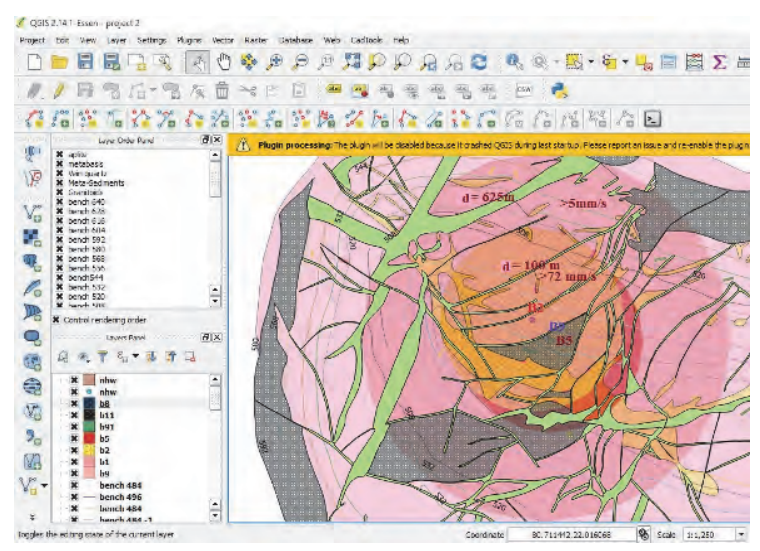

Fig.9. Thematic map Showing South Foot Wall Zone

\subsubsection{North Hangwall Zone}

- From the blasts carried out in adjacent to Granitoid rock mass where the joints are exist with low spacing, the ppv 
waves generated to the highest values in the order of 15 and $14.2 \mathrm{~mm} / \mathrm{s}$.

- However, when the granitoid is intruded by the metabasis and high level of discontinuity resulting in showing the ppv value of $6.18 \mathrm{~mm} / \mathrm{s}$ against the $\mathrm{ppv}$ value of $12.4 \mathrm{~mm} / \mathrm{s}$ in massive granitoid for the maximum charge per delay of $150 \mathrm{~kg}$, due to presence of such discontinuities as well as the blasts were carried out in sheared zones.

- As the zone was free from such contact and sheared zones, the blasts carried out in metabasis zones are producing the vibration levels (ppv) of $11.6 \mathrm{~mm} / \mathrm{s}$.

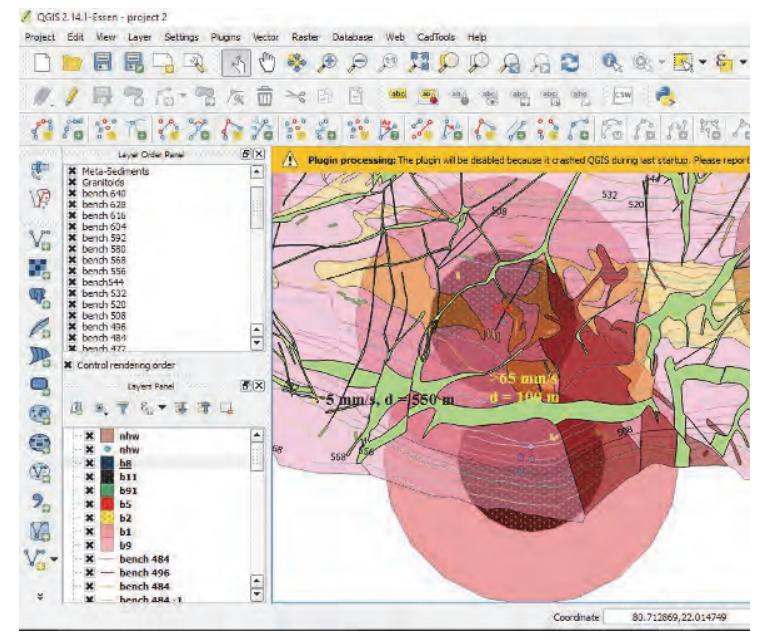

Fig.10. Thematic map showing North Hang wall Zone

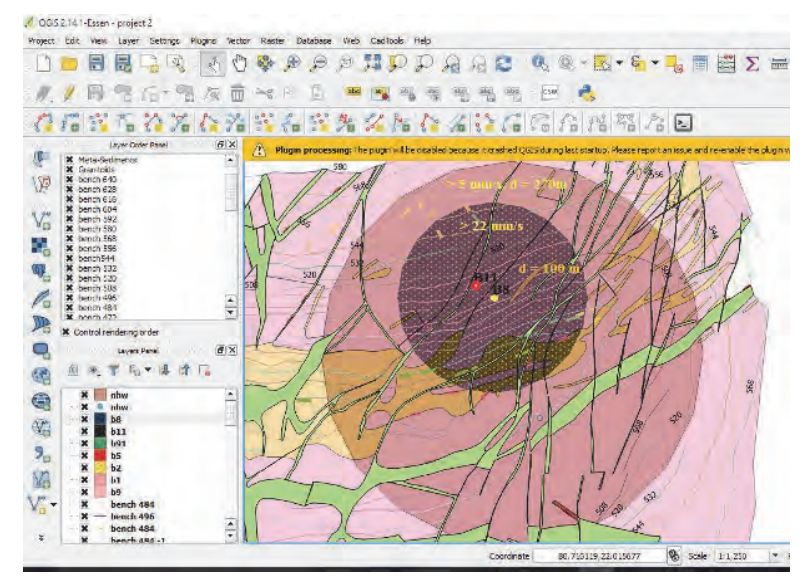

Fig.11. Thematic map showing North Footwall zone

\subsubsection{North footwall Zone}

In the case of North Footwall Zone and in different levels (496 and $508 \mathrm{NFW}$ ) which has been completely formed of granitiods and intruded by quartz vein and metasediment formation, the blasts has produced least level of vibration (ppv) of $3.13 \mathrm{~mm} / \mathrm{s}$ compared to the other zones even at a distance of $1650 \mathrm{~m}$ behind the blast where the shaft construction for the proposed underground mine is being carried out. methods of modeling these vibrations have been used earlier that do not incorporate the material and properties of rockmass have produced a number of uncertainties. In this study, an attempt has been made to evaluate the relationship between the damping behaviour of blast-induced ground vibration [12] and the characteristics of the rock using an appropriate GIS tool.

The stability of the benches in deep open pit mine is utmost important which largely depends on the in-situ stresses and the extent of discontinuities. The orientation of the existing joints or any other openings may be kept more or less along the direction of major horizontal stress when the blasts are being carried out in such geologically highly disturbed benches in deep open pit mines as the instabilities resulting out of discontinuities likely to form vulnerable wedges. Therefore, the other factors that may influence the formation of development of blast-induced vibrations needs to be considered in site-specific constants representing the geology of the site in addition to the propagation and damping characteristics of the ground vibration.

\section{REFERENCES}

[1] Bhandari, S,"Rock Blasting Operations", A. A. Balkema, Rotterdam, 390p, 1997.

[2] Konya, C. J. and Walter, E. J., "Surface Blast Design", Prentice Hall Inc, New Jersey, 297p, 1990.

[3] Balamadeswaran, P. Mishra, A.K, Phalguni Sen, and Magesh, G.R., "Prediction of Rock Fragmentation due to Blasting in Limestone Quarry Using Image Analysis", Proceedings of National Seminar on Recent Practices andInnoations in Mining Industry, Department of Mining Engineering, National Institute of Technology, Raipur, February 19 20, Raipur, pp.01-07, 2016.

[4] Siskind, D.E."Vibrations from blasting", International Society of Explosives Engineers (ISEE), USA, 120p, 2000.

[5] Görgülü Kazim, Ercan Arpaz, Ahmet Demirci, Arzu Koçaslan, M. Kürsat Dilmaç, A. Gürkan Yüksek, "Investigation of blast-induced ground vibrations in the Tülü boron open pit mine", Bulletin of Engineering Geology and the Environment, Volume 72, Issue 3-4, pp 555-564, 2013.

[6] Singh, D.P., Singh, T.N. and Goyal, M, "Ground vibration due to blasting and its effect", In: Pradhan, G.K., Hota, J..K, editors., ENVIROMIN, Bhubaneshwar, India, pp. 287-93, 1994a.

[7] Wiss, J.F. and Linehan, P.W, "Control of vibration and air noise from surface coal mines-III". Report no. OFR 103 (3)-79, Bureau of Mines, US, pp. 623, 1978.

[8] Fourney, W.L., Dick, R.D., Wang, X.J. and Wei, Y,"Fragmentation mechanisms in crater blasting", Int J Rock Mech Min Sci Geomech Abstr, Vol. 30, pp.413-429, 1993.

[9] Singh, D.P. and Sastry, V.R. "Rock fragmentation by blasting influence of joint filling material", J Explos Engg, pp.18-27, 1986.

[10] Pandey, P.K., Sharma, R., Roy, M., Pandey, M.,"Toxic mine drainage form Asia"s biggest copper mine at Malanjkhand", India, Environ Geochem Health 29, 237-248, 2007.

[11] Sauvage, A.C.,"Applied method integrating rock mass in design", Proceedings of International Symposium on Rock Fragmentation by Blasting (FRAGBLAST-10), Singh \& Sinha (Eds), New Delhi, pp.77-83, 2012.

[12] Hustrulid, W., "Blasting Principles for Open Pit Mining", Vol.1, General Design Concepts, A.A. Balkema, Rotterdam, 344p, 1999. 